\title{
Teacher Education \& Curriculum
}

\author{
Dr. Anuradha Goswami and Dr.Vikas Sharma
}

\begin{abstract}
Teacher education refers to the policies and procedures designed to equip prospective teachers with the knowledge, attitudes, behaviours and skills they require to perform their tasks effectively in the classroom, school and community. In 1993, National Council for Teacher Education (NCTE) was set up for the maintenance of standards and improvement of the quality of teacher education in the country. The quality of teacher education not only depends on professionally sound and relevant curriculum, but also on the way the curriculum is implemented in teacher education institutions. Teacher education provides a platform to studentteachers to acquire knowledge, skill and develop positive attitude, values and beliefs. This can be done with the help of the provided curriculum.

Teacher education is an integral component of the Indian educational system. The constitutional goals, the directive principles of the state policy, the socioeconomic problems and the growth of the knowledge, the emerging expectations and the changes operating in education, etc. call for an appropriate response from a futuristic education system and provide the perspective within which teacher education programmes need to be viewed. Teacher education is closely associated with social change. For social excellence effective teaching plays a very significant role.

The education system of our country is one poised for a leap forward towards the 21 st century and is in the process of remarkable transformation. No education reform is possible without the teacher. The teacher's proficiency is ensured through improvement of teacher education. That is why all committees and commissions on education have laid great stress on teacher education. Particularly, it is imperative to develop pre-service teacher education programme which calls for updating and orientating the syllabi and curricula of teacher education accordingly and adequately. Syllabi and curricula are like the constitution of a nation that determines the nature and quality of teacher education.
\end{abstract}

\section{Dr. Anuradha Goswami Assistant Professor Education, DDE, University of Jammu-180006}

For students teachers are role-models. A teacher's prime responsibility is to help students become good human beings, motivated to fulfil their true potential not only for their own benefit but also for the betterment of the society as a whole. An understanding of emerging Indian society and factors and forces operating behind it are essential for developing educational insight among teachers. The knowledge of various components of senior secondary education in the academic stream will enable them to understand its nature, purpose, philosophy and problems. They will be aware of the curriculum, pedagogy and evaluation techniques relevant to this stage and acquire the knowledge of psychology of teaching, learning and transacting the curriculum and the action research to solve day-to-day problems.

Teachers will acquire knowledge of the methods of teaching in depth and develop related competencies by means of the specialised programmes. Practical work, the pedagogical analysis of the subject and practice teaching in the class under the supervision of the expert will inculcate among them needed competencies.

The National curriculum frame work for teacher education (NCFTE, 2009) elaborate the context, concerns and vision underscoring that teacher education and school education have a symbiotic relationship and development in both these sectors mutually reinforce the concerns necessary for qualitative improvement of the entire spectrum of education including teacher education as well.

A new approach to curricular areas of teacher education has been highlighted. The curriculum of teacher education is broadly dealt with under foundations of education, curriculum and pedagogy and school internship. The foundations of education include learner studies, contemporary studies, and educational studies. Curriculum and pedagogy deal with curriculum studies, pedagogic studies and assessment and evaluation studies. Thus, the need of hour is that education should not make the teaching but it must also provide the teacher with a vivid awareness of the great issues and concerns of present time.

\section{CONCLUSION}

Teacher education being an integral part of the educational system is closely connected with improvement of education in general and preparing suitable teachers in particular. Teacher education programmes at all stages should provide opportunities to the would be teachers for understanding the self and others. Teacher must know the current research and practice which can be used effectively to match special 
teaching procedures for children with special needs.Therefore, this paradigm shift in teacher education has resulted in increased duration of teacher education programmes, standard based curriculum as per National curriculum framework for teacher education(2009), balance in the theory and practice, shift from teacher to student centred delivery system, quality assurance, assessment procedures, and this requires redesigning and reorganization of the pre-services and in-service teacher education programmes to meet the present challenges of the society in general and teacher education in particular.

\section{REFERENCES}

[1] Jagannath Mohanty, "Teacher Education".

[2] Jayantibhai V Patel (2015), "Promoting peace through teacher education curriculum", University News, Vol. 53, No. 43, Oct26-Nov 01, 2015.

[3] Kartar Singh and Neetu Singh (2015), "Prospective teacher as constructor of knowledge in pre-service teacher education programme", University News, Vol. 53, No. 26, June 29-July 05,2015.

[4] M.S. Khan, "Teacher Education in India and Abroad".

[5] Mohit Chakrabati, "Teacher education - Modern Trends".

[6] National curriculum framework for teacher education, NCTE Document 2009/10. 